\title{
Governo e Poder em Foucault ${ }^{1}$
}

\author{
Monica Loyola Stival
}

\begin{abstract}
RESUMO: O presente artigo mostra que o conceito de "governo" de Michel Foucault ocupa o espaço aberto por sua crítica ao poder moderno. Foucault passa aos poucos do conceito de poder à noçáo de governo em suas análises. Porém, não se trata de substituição de conceitos equivalentes, mas de um refinamento conceitual que ilumina a dimensão da atividade dos sujeitos como base das relaçôes sociais e políticas modernas. Assim, este texto tem dois momentos distintos e complementares: mostra a possibilidade de passar do conceito de poder ao conceito de governo, pelo menos como elemento central da análise social e política, e discute o alcance do conceito de governo, que se instala em uma dimensão diferente daquela do poder.
\end{abstract}

PALAVRAS-CHAVE: Poder. Governo. Foucault. Atividade. Política.

O movimento de refinamento conceitual que este artigo explora aparece explicitamente enunciado por Foucault no início dos anos 1980: a noção de governo "[...] parece ser muito mais operatória que a noção de poder." (FOUCAULT, 2012, p. 13). Para discutir o conceito de governo, o artigo se concentra no movimento interno da pesquisa de Foucault. Afinal, uma vez que Foucault elabora sua crítica ao conceito moderno de poder $^{3}-$ no sentido amplo, relativo à longa modernidade que nasce no século XVI/XVII torna-se urgente situar o que é, doravante, "poder", seu sentido conceitual e a dimensão que lhe é própria, para então situar a noção de governo

Em linhas gerais, poder se define como a assimetria presente nas relaçóes sociais das mais diversas naturezas, inclusive, mas não especialmente,

\footnotetext{
${ }^{1}$ Este artigo é parte dos resultados de pesquisa financiada pelo Conselho Nacional de Desenvolvimento Científico e Tecnológico (CNPq) por meio do EditalUniversal 14 / 2014.

http://dx.doi.org/10.1590/S0101-31732016000400006

${ }^{2}$ Professora de Filosofia Política no Departamento de Filosofia e Metodologia das Ciências da UFSCar. Mestre e Doutora em Filosofia pela USP, autora dos livros Subjetividade, espaço e tempo em David Hume (Editora Humanitas/FAPESP, 2015) e Politica e moral em Foucault: entre a crítica e o nominalismo (Ediçóes Loyola, 2015). E-mail: stivalmonica@gmail.com

3 Discuti a crítica de Foucault ao conceito de poder em artigo intitulado "Foucault e o fim do poder moderno", publicado na Revista DoisPontos, v. 13, n. 2, 2016, do qual este artigo é uma continuação. Agradeço a leitura dos dois artigos e os comentários de Maria Isabel Limongi.
} 
nas relaçóes jurídicas. Foucault traz ao primeiro plano o conceito de "governo" para alcançar a formação das relaçóes de poder, que são certo corte nas relaçóes de força, espécie de assimetria da qual se pode dar a gênese, mas não a razão. Esse conceito destaca a relação consigo ou com outros que implica o sujeito na constituição da verdade, do justo, do bem etc. Assim, "poder" torna-se um conceito menos operatório que "governo" porque a situação das diversas relaçôes de poder é determinada por um movimento fundamental de constituição que apenas a noção de governo alcança. "Governar, nesse sentido, é estruturar o campo de ação eventual dos outros" (FOUCAULT, 2001, p. 1056). O governo de si e dos outros de que fala Foucault se refere à produção da verdade e das assimetrias sociais, das quais as "relações de poder" são um corte. Foucault chama o processo dessa produção de "governo", de modo que esse campo conceitual permite a Foucault investigar "[...] todos os modos segundo os quais efetivamente aceita-se o poder.” (FOUCAULT, 2012, p. 77).

O conceito de poder coloca em foco as relaçôes constituídas de assimetria, ainda que possa fornecer, por meio de uma genealogia, a história de sua determinação. Outra coisa, entretanto, é situar a análise na dimensão da efetividade, da ação que produz as relaçóes de poder cujo desenvolvimento a genealogia ilumina. Assim, após compreender o significado de "governo" nas análises das relaçóes sociais e políticas, permitindo devolver às relaçóes concretas o fundamento das relaçóes assimétricas sedimentadas no mundo moderno, pode-se justificar o interesse pelo uso desse conceito, em função da dimensão na qual se instala - essa em que se abre espaço conceitual à atividade constitutiva dos homens em sociedade. Trata-se da dimensão na qual há certo actus em jogo, dimensão em que o propósito do exercício de poder adquire sentido e orienta a ação.

\section{I}

“A verdade é que, em toda parte, 'cidadão' quer menos e menos dizer 'indivíduo político enquanto participante do poder', e cada vez mais 'indivíduo político enquanto codificado pelo poder, determinado inteiramente por ele, produzido por ele'”, nota Lebrun (2007, p. 68), no livro O que é Poder. Essa codificação teria nascido com a modernidade, com o poder político tal como aparece em Hobbes. É por isso que Lebrun supóe que "[...] o que Foucault descreve é o triunfo do Leviatá, é o aperfeiçoamento do Estado hegeliano." (LEBRUN, 2007, p. 73). Entretanto, não é isso que Foucault entende como 
poder, ou pelo menos ele não é apenas essa produtividade do poder político em relação às vidas individuais. Então, o que é poder para Foucault? ${ }^{4}$

Tanto a disciplina, que inicia nos séculos XVII e XVIII, quanto a biopolítica, que nasce um pouco depois, na Inglaterra, colocam em cena uma maneira de pensar o poder como "tecnologia de poder" (já em Marx, por exemplo). Pode-se ver essa tecnologia em funcionamento no exército, na educação ou na sexualidade, como mostra Foucault. Há uma "invenção no nível das formas de poder" que ocorre concretamente, nos séculos XVII, XVIII e XIX, justapondo-se à representação jurídica do poder. Por isso, nesse sentido preciso, "[...] o poder tornou-se materialista. Ele cessa de ser essencialmente jurídico.” (FOUCAULT, 2001, p. 1013). Isso não significa que a representação jurídica do poder tenha saído de cena, mas apenas que há algum tempo ela não é exclusiva na determinação concreta das malhas do poder. Contudo, a descrição da história dessas tecnologias de poder muitas vezes não ultrapassa, ao que parece, a dimensão de análise que encontramos desde os primórdios da modernidade como circunscrição do poder político. Para encontrar as tecnologias de poder que coexistem com a representação jurídica do poder, parece ser útil considerar as relaçóes de poder e, mais do que isso, a constituição dessas relaçôes. Esse horizonte de análise, indicado por Foucault por meio da noçáo de governo, abre uma dimensão a mais nas análises do poder, pois precede a própria relação de poder.

Para chegar a esses conceitos, ou pelo menos para situar a dimensão em que se instalam, vale retomar muito brevemente a crítica de Foucault ao sentido moderno do poder político. O sentido da recusa da noção moderna de poder está na recusa da função do aspecto jurídico do poder político, combinado na noção moderna de representação à força em sentido físico. Trata-se, na combinação entre esses dois aspectos do poder, da posse, posse legítima (potestas) e posse da força (potentia). Porém, há primazia do primeiro aspecto em relação ao segundo. Nesse sentido, o poder é sobretudo resultado de uma alienaçáo, de uma autorização prévia que independe do modo concreto como a relação de forças se determina. Não há propriamente relação em jogo. Ao contrário, o olhar sobre as "relaçóes de poder" com que Foucault procura, num primeiro momento, tomar distância da chave de análise jurídica, enfatiza a equação das forças, a assimetria de uma relação que pode ser de

\footnotetext{
${ }^{4}$ Esta primeira seção, que tem por função esclarecer o ponto de partida e o vocabulário da seção seguinte - que é o foco deste artigo -, retoma, em parte, desenvolvimentos publicados no livro Política e moral em Foucault: entre a crítica e o nominalismo (Edições Loyola, 2015).
} 
diferentes naturezas e que se define no modo concreto dessa desigualdade. É essa diferença de perspectiva que Foucault estabelece no desenvolvimento de sua crítica à noção de poder moderna. Todavia, se essa noção de "relação de poder" ultrapassa o paradigma da posse, ela aparece às vezes como corte na dinâmica de constituição da verdade e revela, assim, a assimetria e sua história, não o modo de sua constituição. Em 1977, por exemplo, Foucault aborda a relação de poder como um corte, como uma espécie de fotografia da relação assimétrica, da qual se poderia traçar a história em uma genealogia. "Toda relação de força implica a cada momento uma relação de poder (que é dela, de certo modo, o corte instantâneo), e cada relação de poder reenvia, como a seu efeito mas também como a sua condição de possibilidade, a um campo político do qual ela faz parte." (FOUCAULT, 2001, p. 233).

Por isso, a noção de poder em Foucault, até meados de 1970, é relativamente estática. Ela não envolve propriamente "ação" por parte do sujeito. A proposição mais explícita e conhecida a esse respeito é aquela que propóe a ideia de "estratégia sem estrategista", essa repetida e perigosa formulação funcional que pode dispensar as decisôes políticas de toda responsabilidade moral $^{5}$. É claro que, à primeira vista, parece contraditório afirmar que há uma perspectiva estática justamente quando está em questão a relação de poder. Isso se justifica porque destacar as diferentes relaçôes de assimetria e sua história, numa genealogia das diferenças sociais, não permite passar do sintoma à causa, da constatação à produção, do modo ao fundamento. É aqui que um segundo momento de reflexão sobre o poder aparece na pesquisa de Foucault, passando das "relaçóes de poder" ao "governo de si e dos outros". Vejamos.

Dizer que o poder é produtivo, como faz Foucault nos anos 1970, significa, antes de tudo, dizer que ele colabora na produção da sujeição; mas não se diz com isso como essa sujeição se desenrola. Pode-se mostrar o nascimento de um processo sem, com isso, compreender o mecanismo de constituição desse processo. Foucault procura ultrapassar essa dificuldade em diversos momentos, pois sabe que se desvencilhar do espírito jurídico na análise do poder apenas lançando luz sobre as relaçóes de força não significa muito mais do que girar o mesmo conceito de poder. Foucault sabe perfeitamente que

\footnotetext{
${ }^{5}$ Aqui tomo distância crítica em relação a Foucault, que certamente quis distinguir estratégia e moral. Isso porque, apesar de ter a vantagem de marcar o caráter fluido, contingente e concreto de constituição de um objeto ou sujeito histórico, excluindo a tese simplista de complô, intenção primordial ou conspiraçấo, a ideia de "estratégia sem estrategista" torna os produtos desse conjunto difuso de causas um fato sem sujeitos ativos, sem posição política e moral tomadas durante o processo histórico em questão.
} 
recusar a noção jurídica do poder, o privilégio da potestas, não envolve apenas lançar um olhar direto para os efeitos concretos dessa ordem relativamente abstrata e driblar a racionalização que o poder político faz de si próprio. É isso, todavia, que Zarka sugere. Para ele, seria possível mostrar "[...] como a historiografia de Foucault está ligada à constituição de um conceito não jurídico do poder que permite romper de uma vez com a história do poder, no sentido da história que o poder conta sobre ele mesmo." (ZARKA, 2000, p. 43). Ora, Zarka entende a crítica de Foucault, de maneira simplista, como mera inversáo. Porém, a recusa de Foucault não pode se contentar com a formulação do discurso dos vencidos ao invés de reproduzir o discurso dos vencedores, pois isso não permite passar dos termos dessa assimetria à relação entre eles, e muito menos aos fundamentos dessa relação. Muito mais que criticar o ponto de vista da historiografia, Foucault ensaia, desde meados dos anos 70, uma revisão do conceito moderno de poder.

Em 1981, Foucault se propõe “[...] mostrar em que direção pode-se desenvolver uma análise do poder que não seja simplesmente uma concepçáo jurídica, negativa do poder, mas uma concepção de uma tecnologia do poder." (FOUCAULT, 2001, p. 1002). Esse projeto faz parte de um longo percurso que procura encarar o poder de outro modo, partindo de uma perspectiva que não coloque desde início a questão da lei, da proibição e, com isso, a questão da medida do direito. E, se o primeiro momento da revisão conceitual de Foucault é a afirmação da relação de poder como objeto, já muito além de um posicionamento na estrutura tradicional do conceito, parece haver ainda um longo e movediço caminho para repensar o poder. De todo modo, no percurso levado a cabo por Foucault, o poder político passa paulatinamente do primeiro ao segundo plano das análises sobre as relaçóes de assimetria na sociedade. Nesse percurso, ganha importância a assimetria fundamentada em certa racionalidade, certa verdade, certa ascendência moral totalmente distinta da distância jurídica ou dominação coercitiva que o conceito moderno levou às últimas consequências.

Com efeito, "governo" é um conceito operatório, quando é compreendido

[...] não no sentido estreito e atual de instância suprema das decisóes executivas e administrativas nos sistemas estatais, mas no sentido largo, e aliás antigo, de mecanismos e procedimentos destinados a conduzir os homens, a dirigir a conduta dos homens, a conduzir a conduta dos homens. (FOUCAULT, 2012, p. 13-14). 
Portanto, o governo não está vinculado de partida à forma do Estado. A condução dos homens não estaria, por conseguinte, considerando-se a noção de governo, determinada exclusivamente pelo modelo estatal de poder, mas, particularmente, pela forma de determinação da verdade, da racionalidade. Com isso, é possível desenraizar os valores vigentes. Afinal, a verdade ou a razão em jogo em um sistema social determinado organiza a ação dos homens que a compóem, e não tanto a forma administrativa - esta última é um dos modos de definição concreta da verdade e da razáo, responsável por sedimentar relaçôes de poder atuais. Portanto, governo é o tipo de relação consigo ou com outrem que orienta a ação, por delimitar suas possibilidades, e, dessa forma, produz relaçóes de poder, pois produz diretamente no outro certa qualidade.

O governo dos homens pelos homens - que formem eles grupos de modestos ou importantes, que se trate do poder dos homens sobre as mulheres, dos adultos sobre as crianças, de uma classe sobre uma outra, ou de uma burocracia sobre uma populaçáo - supóe uma certa forma de racionalidade, e não uma violência instrumental. (FOUCAULT, 2001, p. 980).

É preciso, ou pelo menos possível, então, reformular essa racionalidade, mais do que combater alguma violência instrumental.

No quadro conceitual proposto por Foucault, portanto, governo é o modo concreto de uma governamentalidade específica e não necessária. Quer dizer, há um campo no qual certas formas de governo de si e dos outros tomam corpo, fornecendo sentido às relações e estabelecendo distinções e significaçóes. Assim, por ampliar a perspectiva e recuar ao campo aberto em que as relaçóes de poder se estabelecem e dão forma a uma racionalidade específica, o estudo da governamentalidade é decisivo na revisáo do conceito de poder.

Quanto ao estudo da "governamentalidade", ele respondia a um duplo objetivo: fazer a crítica necessária das concepçôes correntes de "poder" (mais ou menos confusamente pensado como um sistema unitário, organizado em torno de um centro que é dele ao mesmo tempo a fonte, $\mathrm{e}$ que é levado por sua dinâmica interna a se expandir sempre); analisá-la, ao contrário, como um domínio de relaçóes estratégicas entre indivíduos ou grupos - relaçôes que têm por questáo a conduta do outro ou dos outros, e que têm recurso, segundo o caso, segundo os quadros institucionais em que elas se desenrolam, segundo os grupos sociais, segundo as épocas, a procedimentos e técnicas diversas. (FOUCAULT, 2014, p. 300). 
Esse domínio das relações estratégicas é a governamentalidade, e governo é o modo concreto dessas estratégias, o que envolve as relaçóes de poder em um campo aberto no qual a unidade do poder se dissolve em diversas formas de relação (o que está longe de significar alguma homogeneidade entre todos os que estão implicados nessas relaçóes ou ignorar a força do poder estatal, como supóem algumas leituras rasas da questão).

\section{II}

Qual dimensão da experiência a noção de governo alcança, já que, segundo Foucault, é mais operatória que a noção de poder? Aqui é preciso fazer um recuo e retomar alguns sentidos do termo "poder", a fim de delimitar a dimensão na qual o conceito de governo permite situar a análise.

Lebrun inicia $O$ que é poder tratando do "poder" entendido como potência. "No domínio das relações políticas, esta potência - não de tornar-se, mas de exercer-se - é a única que pode interessar-nos." (LEBRUN, 2007, p. 11). O poder (potência; dunamis) define-se pela possibilidade de seu exercício. Em seguida, Lebrun adota a definição de Freund para situar o que é "a política” (assim, no feminino): "A atividade social que se propóe a garantir pela força, fundada geralmente no direito, a segurança externa e a concórdia interna de uma unidade política particular[...].” (LEBRUN, 2007, p. 11). Curiosa definição, já que ela coincide com os termos do Leviatã, ao aliar força e legitimidade. Essa definição torna equivalentes "política" e "poder", combinando os aspectos físico e jurídico do poder, assim como em Hobbes.

Lebrun quer com isso enfatizar, desde o início, a força que compóe a política. E como ele define "força"? De uma maneira próxima de como Hobbes define "poder", isto é, como meio. "Assim, a força não significa necessariamente a posse de meios violentos de coerção, mas de meios que me permitam influir no comportamento de outra pessoa." (LEBRUN, 2007, p. 11-12). Para Hobbes, a amizade ou a servidão são modos pelos quais homens exercem poder sobre outros homens. Assim, se Lebrun assegura que "a força é a canalização da potência”, é possível dizer que, para ele, a política pode exercer-se (potência) por meio da influência no comportamento das pessoas, visto que essas pessoas aumentam os meios (poder, força) desse exercício pela amizade ou servidão. Se a força é meio, de que modo são estabelecidos os fins? "Potência (Macht) significa toda oportunidade de impor a sua própria 
vontade, no interior de uma relação social, até mesmo contra resistências, pouco importando em que repouse tal oportunidade" - esta é a fórmula de Weber, também adotada por Lebrun. Com isso, os fins, como, aliás, sustenta Hobbes, são postos pela vontade, e o poder é a possibilidade de impor essa vontade (para o que é preciso dispor de meios) ${ }^{6}$.

Até aqui, o poder (potência; dunamis) continua idêntico à posse de meios para atingir determinados fins. Porém, há um "elemento suplementar" no poder, nota Lebrun, que diz respeito ao "[...] modo da ordem dirigida a alguém que, presume-se, deve cumpri-la." (LEBRUN, 2007, p.12). O dever e a obediência aparecem nesse elemento suplementar, que agrega à potência (dunamis) a dominação (dominus). Vale notar que o elemento suplementar do poder não é da ordem da ação, não é o complemento da capacidade pela efetividade (ergon). Trata-se da dominaçáo, que deve por si mesma - por sua natureza e posição - garantir o cumprimento da ordem. A obediência, nesse sentido, não está vinculada ao ato (ergon), mas à potência, isto é, à “[...] capacidade de efetuar um desempenho determinado, ainda que o ator nunca passe ao ato." (LEBRUN, 2007, p. 10).

De acordo com a teoria da representação de Hobbes, poderíamos traduzir esse sentido de dominaçáo como capacidade ou autoridade do ator para efetuar um desempenho determinado, ainda que esse representante (ator) nunca exerça seu poder, nunca mobilize os meios de que presentemente dispóe nesse sentido determinado. Isso porque a relação de ordem e obediência, desde Hobbes, fundamenta-se geralmente na dimensão do mando, na dimensão da ordem. É nessa dimensão que a potência (dunamis) e a dominação (dominus) se definem, assim como potentia e potestas. A força e a autoridade são geralmente analisadas nessa dimensão da ordem, com diferenças secundárias, de Hobbes a Lebrun. Foucault reconhece, nos anos 1970, a necessidade de transpor essa dimensão de análise. Contudo, num primeiro momento, ele não considera as relaçóes de poder propriamente na dimensão da obediência, da efetividade, na dimensão da constituição dessas relaçôes.

\footnotetext{
${ }^{6}$ Isso significa que, para pensar a democracia como "poder do povo", é preciso mais do que pensar se o povo detém meios para isso (instituiçōes); é preciso pensar se o povo tem vontade. Há uma espécie de "vontade geral"? Há uma unidade política que possa definir uma vontade radical para essa unidade? Nessa chave, "democracia liberal" é um quadrado redondo, pois a vontade é reduzida ao interesse individual como lugar da determinaçấo dos fins. E o que resta ao demos é apenas a definição circunstancial dos meios, dada pela estrutura institucional - a "populaçáo" legitima a forma, não os fins. Esse parece ser o engodo do liberalismo político e de toda aposta no procedimento como elemento principal de uma ordem social justa.
} 
Seriam então "potência" (dunamis) e "dominação" (dominus) termos equivalentes a potentia e potestas? Não exatamente, sobretudo quando se leva em conta a definição de Weber. É com a definição weberiana de poder que Lebrun quer operar sua análise do "poder": "A dominação é, segundo Max Weber, "[...] 'a probabilidade de que uma ordem com um determinado conteúdo específico seja seguida por um dado grupo de pessoas'." (LEBRUN, 2007, p. 13). Como categoria sociológica, a dominação não se reduz aqui à potestas, pois considera a possibilidade de que a ordem se efetive, e não apenas a legitimidade a priori (jurídica, formal) da ordem. Tendo em vista o desenvolvimento de Lebrun a respeito do poder, ele adverte o leitor que doravante "poder" se refere a essa noção weberiana de dominação. Nesse caso, o poder político é "[...] uma ação imposta por um ator a um outro ator" Porém, o que sobra de "ator" àquele a quem uma ação é imposta? Que o poder seja produtivo, como sublinha Foucault nos anos 1970, não quer dizer que a relação de poder seja uma relação entre atores. "O poder, no fundo, é menos da ordem do enfrentamento entre dois adversários, ou do engajamento de um em relação ao outro, que da ordem do 'governo", e governo significa "[...] a maneira de dirigir a conduta de indivíduos ou de grupos" (FOUCAULT, 2001, p. 1056). Porém, vale mencionar, é como relação entre atores que Honneth apresenta o que seria, segundo ele, a "teoria do poder" de Foucault".

Lebrun enfatiza a força porque ele pretende advogar pela tradição que supostamente mantém a reflexão sobre o poder como problema do conflito, sem dissolvê-lo em um modo de relação não coercitivo. Este seria o caso de Parsons. Segundo Lebrun, nessa mesma linha de Parsons está Hegel, porque há nesta filosofia política "[...] esta mesma vontade de dissolver o poder (no sentido weberiano).” (LEBRUN, 2007, p. 14). Lebrun situa, assim, a "dialética pacificadora”, esse materialismo dialético que procura silenciar o conflito. Nisso

\footnotetext{
${ }^{7}$ É como sinônimo de potestas que dominium aparece na passagem de Strauss: "potestas (ou jus, ou dominium)" (STRAUSS, 2014).

8 A tradução por "imperative control" proposta por Parsons teria o inconveniente de minimizar, como nota Lebrun, "[...] o papel da coerçâo e elimina(r) o caráter dissimétrico, não igualitário, hierárquico, em suma, do poder." (LEBRUN, 2007, p. 14).

${ }^{9}$ Honneth desenvolve, em Kritik der Macht, de 1985, três capítulos a respeito do que entende ser a filosofia de Foucault. No primeiro, expóe traços gerais do que seria o estruturalismo foucaultiano - assunto de que não tratarei diretamente, observando apenas que o sentido da crítica de Foucault às "filosofias da reflexáo" não se reduz a uma posiçấo estruturalista que abrisse a possibilidade de uma etnologia da Europa moderna. No segundo capítulo, Honneth apresenta a suposta "teoria do poder" de Foucault, a partir do paradigma da luta, entendida por ele como relaçáo de oposiçáo entre "atores". Com isso, Honneth faz uma interpretação equivocada da questão do poder, em Foucault, imprimindo artificialmente a dinâmica da ação nas relaçōes de poder. Mencionarei o terceiro capítulo no corpo do texto.
} 
Foucault está de acordo com Lebrun, pois caracteriza a dialética hegeliana e todas as que a seguiram como responsáveis pela "pacificação autoritária" do discurso histórico-político. "A dialética é a pacificação, pela ordem filosófica e talvez pela ordem política, desse discurso amargo e partidário da guerra fundamental." (FOUCAULT, 1997, p. 50). Entretanto, manter a ideia de que o poder é também coerção não significa identificar poder e coerção essencialmente.

Lebrun situa Hobbes no lugar oposto ao que Foucault lhe reserva, porque vê nele a primazia da força, enquanto Foucault vê em Hobbes o privilégio do direito. Lebrun vê em Hobbes o contraponto da pacificação pela forma jurídica, enquanto Foucault vê Hobbes como o maior exemplo dessa pacificação. De todo modo, ambos enxergam em Hegel a perspectiva da dissolução do conflito. É o que Lebrun chama de dissolução do poder (como dominação, portanto, com coerção) na autoridade. Se Lebrun está de acordo com Foucault na acusação de que a dialética obscurece o conflito, a relação de forças, então a diferença entre o que um e outro entende por "poder" reduz-se à interpretação de Hobbes?

A tese de que a obediência política tem na coerção um elemento indispensável náo implica a teoria sociológica da soma zero, como afirma Lebrun. É por isso que se pode passar de Weber a Foucault. Porém, Lebrun (2007, p. 18) localiza Weber no seu próprio time, com outros tantos insuspeitos, como Marx, Nietzsche, Aron e Mills. Do outro lado do campo estariam Foucault e Parsons, ainda que por motivos muito diferentes. Para Lebrun, a recusa da teoria da soma zero significa negar que a obediência política ocorra como coerção. Contudo, Foucault pode recusar a teoria da soma zero sem, entretanto, discordar absolutamente da implicação entre obediência política e coerção, já que a coerção é para ele um dos aspectos possíveis de um poder produtivo e não exclusivamente coercitivo ${ }^{10}$. Com isso, Foucault pode pensar a "teoria do poder", nos anos 1970, a partir da ideia de que o poder coage e inspira, cerceia e libera, repreende e produz. Pode-se dizer, seguindo a definição weberiana da qual parte Lebrun, que a dominação (dominus = senhor) é pensada como vontade imposta que produz certa "vontade de servidáo", pois o "escravo" é também sujeito da relação entre senhor e escravo.

\footnotetext{
${ }^{10}$ Vale notar que é preciso ter cautela ao atribuir a "descoberta” de uma relação conceitual não necessária a este ou aquele autor. "O problema que Clastres descobriu, o da coincidência fortuita entre poder e coerção, é um daqueles que a direita precisa esconder.” (VIVEIROS DE CASTRO, 2014, p. 311-312). De todo modo, essa indicação tem a vantagem de situar a orientaçấo política que Lebrun toma, ao vincular essencialmente os termos poder e coerção.
} 
Assim, nesse caso, o estatuto da coerção é diferente da força que caracterizava a teoria moderna do poder. $\mathrm{Na}$ teoria moderna de espírito hobbesiano, a força não diz respeito a uma relação de forças, mas a uma potência (potentia ou dunamis) exclusiva do senhor (dominus). Ao contrário, o campo do poder se desenha em Foucault fora da estrutura estrita do poder jurídico aliado à força da espada (ambiguidade entre potestas e potentia em Hobbes) e também fora da estrutura sociológica da dominação, entendida como espécie de força simbólica aliada à força física pelo monopólio da violência (dominus e dunamis em Weber e Lebrun). Ao ampliar o sentido do poder para além da dominação, Foucault inicia uma inversão que só se conclui com a sobreposição do governo em relaçáo ao poder enquanto categoria central de análise social e política. Mesmo antes dessa sobreposição, o poder produtivo que se define nas relaçóes permite pensar a coerção como um aspecto do poder. A questão da coerção e da obediência ganha novos contornos, de modo que a passagem necessária anunciada por Lebrun entre teoria da soma zero e definição do poder pela coerção revela-se uma simples possibilidade. Se podemos questionar o efeito, vejamos também qual seria a causa. Lebrun traz Foucault ao texto, para argumentar contra este que seria o contraponto mais relevante à sua filiação à teoria da soma zero.

$\mathrm{Na}$ teoria da soma zero trata-se de entender o poder como "[...] uma soma fixa, tal que o poder de A implica o náo poder de B” (LEBRUN, 2007, p. 18). Há um sujeito na posição superior, um outro na posição inferior, definidos em função da possibilidade de o primeiro impor sua vontade ao segundo - ou, pelo menos, que o segundo siga a ordem estabelecida pelo superior. A soma zero se concretiza, para Lebrun, não tanto no modelo de classes, mas de valores que disputam a posição superior, cuja função é irredutível nas organizaçōes políticas modernas. Quer dizer, Lebrun (2007, p. 19) entende que "[...] nenhuma organização política, pelo menos moderna, poderia funcionar sem haver dominação - e que o único problema político é, então, saber qual é o melhor modo de determinar e adequar esta última - em função, é claro, dos valores e da escala de valores escolhidos”. Mas, então, em que Lebrun se distingue de Foucault? Foucault não é, afinal, um dos autores que entende o conflito como condição irredutível? Não estáo ambos de acordo contra a "dialética pacificadora"?

A questão é que a irredutibilidade do conflito pode ser pensada a partir da dominaçáo e da relação de poder como soma zero, num sistema de equivalências, como faz Lebrun, ou pode ser pensada como jogo de forças 
que não se anulam, mas que produzem resistência ao mesmo tempo em que cerceiam, como quer Foucault. Lebrun acusa Foucault de reduzir seu escopo aos pequenos poderes, dimensão na qual se justifica uma "teoria do poder" fluida. Afinal, aquele jogo de poder não se desenrola na matriz "ordem e obediência”, que é a matriz da soberania, mas nas múltiplas relaçôes de poder - o que não descarta, é preciso ressaltar, o poder político. Com uma teoria do poder fluida, solta em uma infinidade de relações microfísicas, Foucault perderia de vista, assegura Lebrun, a "[...] matriz 'ordem/obediência' ('eu tenho poder, portanto você não o tem’) [...].” (LEBRUN, 2007, p. 21).

Lebrun supóe que Foucault se restringe à disciplina para pensar a obediência, equívoco que se multiplica em diversos comentários recentes à obra de Foucault. A disciplina não é mais que um dispositivo entre outros, central por um período apenas da história da governamentalidade e, ademais, não diz respeito exclusivamente à esfera do Estado ${ }^{11}$. Quando Foucault discute a obediência, em $A$ vontade de saber e em Vigiar e punir, pode-se imaginar que a obediência é pensada por ele exclusivamente na chave da disciplina. Em meados dos anos 70, tem-se o desenvolvimento de uma chave de análise capaz de se contrapor ao modelo jurídico e, ao mesmo tempo, abrir espaço à reflexão sobre a produção da obediência. Porém, pode-se notar que, aos poucos, essa questão da disciplina torna-se ainda mais localizada e secundária em relaçáo ao governo ou à política voltada à população. Trata-se de mais do que disciplina, trata-se de orientar ou conduzir a coletividade, a unidade política, ou ainda a si próprio e aos outros. Para Foucault - a fim de tomar uma dessas direçôes como exemplo -

[...] o meio aparece como um campo de intervençáo em que, em vez de atingir os indivíduos como um conjunto de sujeitos de direito capazes de açóes voluntárias - o que acontecia no caso da soberania -, em vez de atingi-los como uma multiplicidade de organismos, de corpos capazes de

\footnotetext{
${ }^{11}$ É interessante notar que a disciplina no exército, por exemplo, é um modo novo de organização desse conjunto de homens, digamos, para manter a indeterminaçáo. Como aparece a disciplina no exército, ao longo dos séculos XVI, XVII e XVIII? "Toda uma enorme transformação que fez que, no exército, que era até então essencialmente constituído de pequenas unidades de indivíduos relativamente intercambiáveis, organizados em torno de um chefe, essas unidades fossem substituídas por uma grande unidade piramidal, com toda uma série de chefes intermediários, de suboficiais, de técnicos também, essencialmente porque havia sido feita uma descoberta técnica: o fuzil de tiro relativamente rápido e ajustado." (FOUCAULT, 2001, p. 1007). É interessante observar que a disciplina aparece quando se passa de pequenas unidades organizadas em torno de um chefe a uma grande unidade piramidal. Além disso, no primeiro modelo os elementos são intercambiáveis, o que é pressuposto de uma igualdade entre eles, talvez como na sociedade indígena considerada por Pierre Clastres, em contraposição à "unidade hierárquica" do modelo disciplinar, que imprime diferença entre os homens.
} 
desempenhos, e de desempenhos requeridos como na disciplina, vai-se procurar atingir, precisamente, uma população. (FOUCAULT, 2004, p. 23).

Apesar disso, no terceiro capítulo dedicado a Foucault em Kritik der Macht, Honneth procura mostrar o que seria a "teoria da sociedade" de Foucault, generalizando o modelo disciplinar das técnicas de controle e inserindo a relação de poder em uma filosofia da história estranha aos textos de Foucault (quando não é um de seus adversários principais). Honneth compartilha desse recorte que leva Lebrun a generalizar e estender a disciplina por toda modernidade e identificá-la a uma política de Estado. Vejamos como Lebrun (2007, p. 19-20) apresenta o que seriam os argumentos de Foucault contra a "teoria da soma zero" em 1976.

1) Por que reduzir a dominação à proibição, à censura, à repressão escancarada? [...] O poder é menos o controlador de forças que seu produtor e organizador. [...]

2) Se esta verdade ainda passa desapercebida é porque "no fundo, a representação do poder continua sendo obcecada pela monarquia", e pela representação jurídica que esta suscitou. [...] O poder é instaurador de normas, mais que de leis.

3) Deixaremos, então, de representar o poder como uma instância estranha ao corpo social, e de opor o poder ao indivíduo. Afinal de contas, ainda é muito tranquilizante interpretar o poder apenas como "um puro limite imposto à liberdade". [...] Na verdade, encontramos as relaçôes de poder funcionando em relaçôes muito distintas na aparência [...] De modo que, 'no princípio das relações de poder, não existe, como matriz geral, uma oposiçáo binária e global entre dominantes e dominados.

É a recusa dessa matriz geral - recusa de ressonâncias clastrianas - que Lebrun não pode admitir. Entretanto, a disciplina não é o fundamento do que se pode chamar, com o risco de retomar a matriz geral lebruniana, de "obediência". Assim, à primeira vista, Lebrun tem razão ao afirmar que,

[...] quando a questáo é compreender como foi e continua sendo possível a resignação, quase ilimitada, dos homens perante os excessos do poder, náo basta invocar as "disciplinas" e as mil fórmulas de adestramento que, como mostra Foucault, são achados relativamente recentes da modernidade. (LEBRUN, 2007, p. 21). 
De fato, não basta. Todavia, as disciplinas são apenas um sintoma da hegemonia, isto é, do modo como o discurso verdadeiro engendra relaçóes de poder determinadas no Ocidente. É isso que Foucault notou particularmente no final dos anos 1970 .

É nessa dimensão do governo que se pode pensar, com Foucault, a produção da verdade, a produção do discurso verdadeiro que distingue senhor e escravo, a produção da legitimaçáo da dominação, anterior à imposição da vontade. A vontade já não é previamente autorizada a pôr fins, como na estrutura jurídica do Leviatã. Não se trata, pois, de "autorização", de autoridade. Trata-se de produção da verdade e das assimetrias (das relaçóes de poder) por meio do governo de si e dos outros. Portanto, para Foucault, não há o que Lebrun chama de um "sentimento atávico dos deserdados, de serem por natureza excluidos do poder", mas há certo assentimento à verdade, uma constituição de si próprio (dos sujeitos) por um discurso que sustenta e produz as distinçôes sociais - doravante, distinçôes verdadeiras, por oposição a naturais. Os sujeitos náo se veem como sendo por natureza excluídos do poder, mas entendem muitas vezes a exclusão como a verdade do sistema, sua racionalidade inquestionável.

Lebrun procura criticar Foucault, dizendo que “[...] ainda que o poder não seja uma coisa, ele torna-se uma, pois é assim que a maioria dos homens o representa...” (LEBRUN, 2007, p. 21). Ao contrário, diria Foucault, os homens o representam como verdadeiro, não como natural; nesse sentido, ele não se torna uma coisa, mas se torna racional. Trata-se menos de um sentimento do que de uma racionalização.

\section{III}

Com isso, Foucault opera uma inversão decisiva na maneira de analisar as relaçôes de poder: pensar a obediência a partir da coerção significa pensar a matriz "ordem/obediência" com base na ordem; enquanto Foucault traz o sentido da obediência ao primeiro plano, traz o sujeito deserdado ao centro. A obediência não é submissão ou resignação, mas signo de certa racionalidade, signo de uma imagem do mundo e de si mesmo nesse mundo. Assim, não seria o caso de entender que a burocracia e a técnica relativas ao poder político moderno, como quer Lebrun, são resultado de “[...] uma longa evolução, cujo ponto de origem seria o momento em que se tornou óbvio que 'comunidade 
política' = 'organização da dominação'.” (LEBRUN, 2007, p. 22). Porém, elas seriam resultado de uma longa evoluçáo, cujo ponto de origem estaria no momento em que se tornou óbvio que "comunidade política" = "discurso que se apresenta como verdadeiro" ou até mesmo "imagem de mundo".

Essa diferença não explicaria a observação humiana à qual Lebrun se refere, segundo a qual os homens podem eventualmente manter a sociedade sem governo? Na perspectiva de Foucault, as distinçôes sociais são principalmente efeitos de certa racionalidade, e não tanto efeitos da pura força do governo ${ }^{12}$. A racionalização-chave da modernidade, desde Hobbes, erige-se sobre o mito de que "[...] o nascimento do poder deve-se, aparentemente, às necessidades da guerra". Nessa linha, continua Lebrun no espírito de Hume, "[...] há muito tempo que 'ser cidadão' = 'ser obediente'." (LEBRUN, 2007, p. 24). E ele tem toda razão, quando ressalta que é essa equação "[...] que precede e possibilita o adestramento descrito por Foucault." (LEBRUN, 2007, p. 24). Entretanto, Foucault mostra que tal equação precede a disciplina, se for entendida como uma forma de racionalidade sedimentada, e não como uma "fatalidade". Lebrun precisa admitir que é a fragilidade dessa naturalização que exige que se reponha a cada vez, em toda teoria política, a análise da servidáo voluntária ou o fundamento da obediência. Ao invés de encontrá-la na espada, na razão prática, no monopólio da violência etc., Foucault a reconhece na própria produção racional dos sujeitos. A revisão conceitual do poder possibilita pensar a dimensão dessa produção de racionalidade, a qual pode ser entendida como produção de imagem ou valor (mito). A noção de governo, ao que parece, alcança uma dimensão estranha à matriz moderna da ordem e obediência.

Como nota Strauss, "A potentia e a potestas têm um ponto em comum, a saber, ambas só são inteligíveis em contraposição ao actus, e em relação com ele: a potentia de um homem é o que ele pode fazer, e a potestas ou, em termos mais gerais, o direito de um homem é o que ele tem permissão de fazer." (STRAUSS, 2014, p. 168). A questáo é que a história do poder, desde Hobbes, mantém essa contraposição ao actus, mesmo quando se pretende dessubstancializar o termo e passar do poder de um homem ao poder como relação entre os homens. De algum modo, essa história parece dar razão a Strauss, quando conclui que, "[p]or conseguinte, a predominância do interesse

${ }^{12}$ Muito mais do que repensar o estatuto das relações de poder nas sociedades organizadas na forma Estado (ou governo), a inversão foucaultiana permite pensar as sociedades descritas por Pierre Clastres. Afinal, trata-se daqui em diante de racionalidade e verdade, não de sentimento e natureza. A coerçáo, embora presente como modo de efetivação de certas relações de poder em determinadas sociedades, não explica a organização social nem as relaçôes de poder em seu fundamento. 
pelo 'poder' é apenas a outra face da moeda da relativa indiferença perante o actus, ou, dito de outra forma, perante os propósitos ao serviço dos quais o poder 'físico', assim como o poder 'legal', é ou deve ser utilizado." (STRAUSS, 2014, p. 168). A indiferença perante ao actus é o centro da necessidade da passagem, por Foucault, do poder ao governo.

Contraposição ao actus: na maneira jurídica de pensar o poder, nascida com Hobbes, o que é "a fazer" (agenda) é secundário em relação à forma - o móbil da ação é a forma jurídica que será desse modo garantida, isto é, que será executada por meio do governo dos homens. Por isso, força física e governo se confundem, pois governar não é, nesse caso, nada diferente de executar por meio da potentia o poder, a potestas, manter o dominium sobre os homens. É preciso recuperar o actus para o lugar de móbil da ação de governo; consequentemente, o governo náo pode se reduzir ao articulador da agenda, como ocorre ao governo liberal, se pensarmos a coexistência mutuamente determinante do liberalismo e da democracia representativa. Afinal, aliar assim força e legitimidade seria manter o poder político em sua legitimidade a priori, como forma jurídica, e, com isso, a necessidade da estrutura de poder moderna. Foucault explicita que a ação concernente ao governo é mais que a fraca regulamentação dos deveres, porque ela é na verdade a própria constituição e constante autolegitimação da estrutura de poder. Justamente por isso é preciso falar não em termos de poder, que se confunde com a assimetria formal e a priori do poder político moderno, mas em termos de governo, renovando seu sentido. O governo não é esse governo que, por meio da força física (potentia), garante a estrutura jurídica da sociedade civil, mas é algo que envolve uma atividade constituinte. Dessa maneira, Foucault encontra os elementos necessários para pensar o poder político como governo, envolvendo uma atividade ou exercício que constitui efetivamente os homens, o próprio poder político e que define a natureza das relações sociais. Como a constituição das relaçóes de poder envolve diversos campos de ação, diversas relaçóes e níveis sociais de determinação, é preciso pensar conceitualmente como se dá o governo de si e o governo dos outros.

Isso significa que "governo" é uma noção mais operatória que "poder" porque ela não implica dominação, não implica a matriz ordem/obediência. $\mathrm{O}$ governo político não é exatamente dominação, mas ascendência ${ }^{13}$ moral racionalizada - e só assim ela é uma dominação jurídica (potestas) na história

\footnotetext{
${ }^{13}$ Uso aqui a ideia da ascendência de uns sobre outros como modo do governo político (que não se explica, portanto, como simples representação) em função do papel que o dizer verdadeiro pode ter no jogo político e no exercício de governo, segundo Foucault: "Eu diria que os problemas da dunasteia são os problemas do jogo político, isto é: da formação, do exercício, da limitação, da garantia também
} 
moderna. Ora, "governo" não envolve necessariamente o mando, a ordem, a imposiçáo de uma vontade independente.

Desta feita, o que podemos apreender de fundamental na reflexão de Foucault sobre poder e governo é a necessidade de recusar a chave clássica em que o poder é geralmente pensado, recusar a matriz geral "ordem e obediência", a qual Lebrun procura manter em cena como elemento principal das relaçóes sociais. Essa matriz implica uma reflexão sobre o poder em termos de forma legítima ou força inviolável, restando à dimensão da resistência a submissão ou a resignação.

Ora, Foucault mostra mais do que a disciplina como dimensão que explicaria certa "resignação" "perante os excessos do poder", como entende Lebrun. Ele procura identificar a constituição da verdade, no plano do regime de verdade social e no nível egoico da verdade de si mesmo, como elemento central dessa "resignação". Assim, parece demasiada violência intelectual supor com Lebrun que "o proletário do Terceiro Mundo" é absolutamente dominado pelo Leviatá, dispensando a delicadeza de ao menos um trabalho mais elaborado de domesticação. Ocorre que, uma vez que a divisão social é instituída, por conquista ou contrato, ou de qualquer outro modo, a busca da homogeneidade precisa aniquilar o poder jurídico, que, entretanto, na racionalizaçáo da nossa modernidade, goza de um poder composto de força e legitimidade - poder que Foucault faz aparecer náo como natural, mas como verdadeiro para (ou em) certa racionalidade.

Assim, a questão clássica da obediência (ou o par "proteção e obediência") é tratada por Foucault em termos de constituiçáo de uma verdade comum, que pode ser o reconhecimento de um lugar, da ascendência de uns em relaçáa aos outros, ou do próprio discurso tido como verdadeiro. $\mathrm{O}$ conceito de governo é mais operatório que o conceito de poder, porque ele diz respeito à dinâmica de constituição dessa verdade e, com ela, à disposição social e política dos homens. Doravante, a assimetria do poder é contingente e, como tal, questionável; não é nem condição jurídica de toda sociedade que evita o caos, nem força física a cujos excessos os fracos se resignam (potestas ou potentia), mas é o espaço positivo de construção de uma verdade.

Em uma conferência para um público norte-americano, Chinua Achebe (2000, p. 33) recorda como os professores britânicos faziam com que os jovens estudantes universitários africanos lessem a literatura europeia.

dada à ascendência que é exercida por certos cidadãos sobre certos outros." (FOUCAULT, 2008, p. 146). Cf. também p. 162 e p. 190. 
Condescendentemente, incluíam um ou outro livro, também europeu, é claro, que falava da "África" - e estes eram os que mais irritavam os estudantes. Mas, nascido em uma dessas sociedades contra o Estado que também pululam no continente africano, os Ibo da Nigéria oriental, Achebe conta que foi a leitura de um desses livros que o obrigou a deixar de lado sua "suposiçáo infantil acerca da inocência das estórias" e o convenceu de que é tão importante para um povo ter o controle de suas estórias (stories) quanto de sua história (history). Porque, ele conclui, "embora a ficção seja indubitavelmente fictícia, ela também pode ser verdadeira ou falsa, não com a verdade ou a falsidade de um noticiário, mas em relação a seu desprendimento [disinterestedness], sua intenção, sua integridade. (GOLDMAN, 2011, p. 595).

A construção da verdade é a construção do mito, da imagem ou representação que orienta as açóes dos homens na dimensão da efetividade, do actus ou ergon. Trata-se da dimensão na qual se definem os propósitos do indivíduo e da coletividade, e que a noção de governo de Foucault permite analisar.

STIVAL, Monica Loyola. Government and power in Foucault. Trans/form/ação, Marília, v.39, n.4, p.107-126, Out./Dez., 2016.

\begin{abstract}
This article shows that Michel Foucault's concept of government occupies the space opened for his critique of modern power. Foucault passes gradually from the concept of power to the notion of government in their analysis. However, it is not a replacement of equivalent concepts, but a conceptual refinement that illuminates the dimension of activity of subjects as the basis of modern social and political relations. Thus, this article has two distinct and complementary stages: it shows the possibility of moving from the concept of power to the concept of government, at least as the central concept to the social and political analysis, and it discusses the scope of the concept of government, which is installed in a different dimension from that of power.
\end{abstract}

KEYWORDS: Power. Government. Foucault. Activity. Politics. 


\section{REFERÊNCIAS}

FOUCAULT, M. Il faut défendre la société: cours au Collège de France (1975-1976). Paris: Hautes Études; Gallimard; Seuil, 1997. . Dits et écrits (1954-1988). Paris: Gallimard, 2001. 2 v. . Sécurité, territoire et population: cours au Collège de France (1977-1978). Paris: Hautes Études; Gallimard ; Seuil, 2004.

Le gouvernement de soi et des autres: cours au Collège de France (1982-1983). Paris : Hautes Études; Gallimard; Seuil, 2008.

. Du gouvernement des vivants (1979-1980). Paris: EHESS; Gallimard; Seuil, 2012. . Subjectivité et vérité (1980-1981). Paris: EHESS; Gallimard; Seuil, 2014.

GOLDMAN, M. Pierre Clastres ou uma Antropologia contra o Estado. Revista de Antropologia, São Paulo, v 54, n. 2, p. 577-599, 2011.

HONNETH, A. Kritik der Macht. Frankfurt am Main: Suhrkamp, 1985.

LEBRUN, G. O que é poder. Tradução Renato Janine Ribeiro e Sílvia Lara. São Paulo: Brasiliense, 2007.

STRAUSS, L. Direito natural e história. Tradução Bruno Simóes. São Paulo: Martins Fontes, 2014.

VIVEIROS DE CASTRO, E. Posfácio a Clastres, P, arqueologia da violência. São Paulo: Cosac Naify, 2014.

ZARKA, Y. Foucault et le concept non juridique du pouvoir. Cités, n. 2, p. 41-52, 2000.

Recebido em 20/11/2015

Aceito em 11/01/2016 
STIVAL, M.L. 